\title{
Analisis Kluster Terpaan Selektif Dalam Jaringan Informasi Vaksin Covid-19 Di Twitter
}

\author{
Fadlih Awwal Hasanuddin, Muh. Akbar, Muhammad Farid \\ Universitas Hasanuddin Makassar \\ Jl. Perentis Kemerdekaan Makassar \\ Email: fadlihasanuddin@ gmail.com
}

Received: 22 August 2021; Revised: 02 October 2021; Accepted: 28 December 2021
DOI: http://dx.doi.org/10.37905/aksara.8.1.713-732.2022

\begin{abstract}
Abstrak
Tujuan penelitian ini adalah untuk mengedintifikasi kluster yang terbentuk dalam jaringan twiter terkait dengan topik-topik vaksin covis-19. Penelitian ini menggunakan pendekatan kuantitatif dengan analisis jaringan sosial dengan metode kluster terpaan selektif. Populasi penelitian ini adalah penggunan jaringan sosial twiter dengan kata kunci "vaksin covid-19' sebagai sampel kluster. Data dikumpulkan dengan menggunakan aplikasi NodeXL. Data dianalisis dengan cara pengelompokan berdasarkan kluster algoritma Clauset-Newman-Moore dengan cara menghitung seluruh jaringan pengguna, tingkat hub dalam kluster, pengelompokan dalam jaringan, menetukan jaringan twiter tertinggi. Hasil penelitian menunjukkan bahwa akun-akun resmi pemerintah, tokoh politik, dan media massa secara bersamaan muncul pada seluruh kumpulan data sehingga mereka membentuk kluster secara konsisten mendukung keberhasilan program vaksinasi nasional.
\end{abstract}

Kata Kunci: kluster, terpaan selketif, jaringan informasi, vaksin covid-19

\section{PENDAHULUAN}

Diskursus terkait vaksin COVID-19 saat ini mudah kita dapati dari percakapan ringan di warung kopi, pasar, tempat ibadah, serta di media sosial. Diskursus dapat diartikan sebagai suatu sistem pernyataan yang membangun suatu objek (Parker, 1990). Pernyataan ini sendiri dibentuk dari informasi, baik tertulis (teks) maupun tidak tertulis (lisan). Dari beragam informasi yang tersedia terkait vaksin COVID-19 inilah yang membuat masing-masing individu membangun suatu objek terkait apa itu vaksin yang nantinya akan berpengaruh pada pengambilan keputusan kesehatan mereka. Umpama, media sosial dapat menjadi tempat terjadinya diskursus. Apalagi ditengah pembatasan sosial, media sosial semakin memperkuat posisinya sebagai wadah untuk melakukan interaksi sosial (komunikasi), bertukar informasi, mencari informasi, mencari hiburan, dan lain sebagainya. Informasi ini dapat berisi narasi yang berbeda, dimana masing-masing narasi yang dibangun memiliki pendukungnya sendiri-sendiri. Contohnya di media sosial seperti Facebook, Instagram, Tik Tok, dan Twitter kita dapat melihat berbagai macam respon dan sentimen netizen terkait vaksin COVID-19. Disini peneliti akan memilih Twitter sebagai objek penelitian karena data Twitter yang sifatnya publik dapat diakses melalui bantuan aplikasi NodeXL. 


\section{A}

AKSARA: Jurnal Ilmu Pendidikan Nonformal

P-ISSN 2407-8018 E-ISSN 2721-7310 DOI prefix 10.37905

Volume 08, (1), January 2022

http://ejurnal.pps.ung.ac.id/index.php/Aksara

\section{Pengguna Twitter di dunia dan Indonesia dalam lima tahun terakhir (dalam juta)}
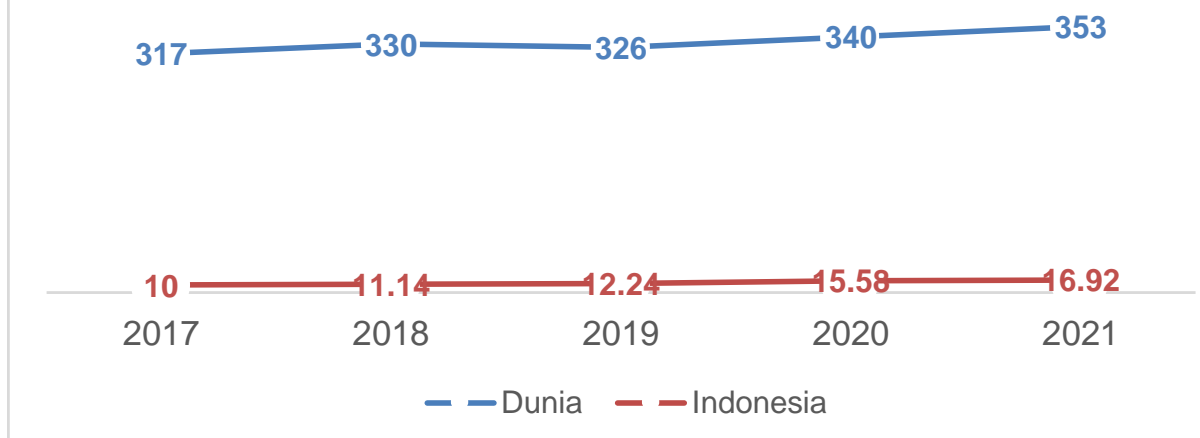

Gambar 0.1: Data pengguna Twitter tahun 2017-2021

Jumlah pengguna Twitter dari tahun 2017-2021 terus menunjukkan tren kenaikan walaupun tidak terlalu signifikan baik di level internasional maupun di level nasional. Pada Gambar I.1 kita dapat melihat jumlah pengguna Twitter di Indonesia lima tahun terakhir mengalami peningkatan sebesar 6,9 juta pengguna pada tahun 2021. Selain itu menurut internetlivestats.com jumlah produksi kicauan perdetik dapat mencapai rata-rata 9.618 kicauan dan akan meningkat drastis jika terdapat momen tertentu. Selain itu, adanya fitur trending topic menjadikan Twitter menjadi unik jika dibandingkan dengan media sosial mainstream lainnya. Fitur ini memungkinan penggunanya untuk dapat mengikuti perkembangan isu/topik hangat apa yang sedang dibicarakan atau terjadi. Fitur ini memungkinkan adanya perengkingan topik berdasarkan traffic kata kunci atau tagar tertentu melalui mekanisme algoritma Twitter. Trending Topic ini juga telah menjadi medan "pertempuran" berbagai kelompok untuk melakukan kampanye dalam rangka mendapatkan perhatian dari netizen.

Kembali kepermasalahan vaksin COVID-19, pada 13 Januari 2021 adalah hari yang menandai dimulainya program vaksinasi ini. Presiden Jokowi adalah orang pertama di Indonesia yang mendapatkan suntikan dosis pertama vaksin COVID-19 yang diproduksi oleh Sinovac yang kemudian diikuti oleh jajaran menteri dan masyarakat yang diwakili oleh beberapa publik figur ternama (Sekretariat Kabinet Republik Indonesia, 2021). Menariknya jika melihat cuitan di Twitter terdapat beberapa akun yang memperlihatkan sentimen negatif terhadap penggunaan vaksin Sinovac. Salah satu narasi yang sering digunakan untuk menyerang penggunaan vaksin Sinovac sering diasosiasikan dengan opini (teks) dan meme anti cina (lihat Gambar I.3). Bahkan beberapa hari sebelum dan sesudah acara peresmian dimulainya program ini tagar \#TolakDivaksinSinovac sempat masuk kedalam jajaran trending topic.

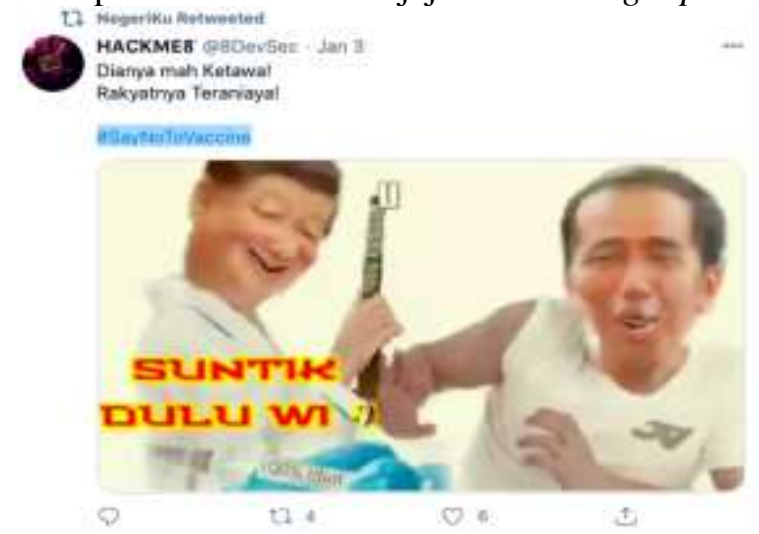

Gambar 0.2 Meme tolak vaksin berdasarkan sentimen anti cina

714 AKSARA: Jurnal Ilmu Pendidikan Nonformal 
Jika menelisik lebih jauh tagar \#TolakDivaksinSinovac sempat berada di rangking pertama trending topic pada tanggal 12 Januari 2021 sehari sebelum acara peresmian pelaksanaan program vaksinasi nasional. Dalam satu detik saja tagar ini berkicau sebanyak 9.943 kicauan. Adapun pengguna tanggar ini seperti @BadutPolitikus membangun narasi yang membandingkan efektivitas vaksin Sinovac dengan vaksin lainnya serta menggunakan narasi lain seperti memilih vaksin yang juga digunakan oleh negara-negara Islam seperti Arab Saudi (lihat Gambar I.4). Selain itu, akun@ustadtengkuzul membangun narasi bahwa sesuatu yang haram dapat digunakan jika sudah darurat dan tidak ada alternatif lain namun kemudian diakhir cuitannya akun ini melontarkan kalimat sinisme terhadap pemerintah (lihat Gambar 03).

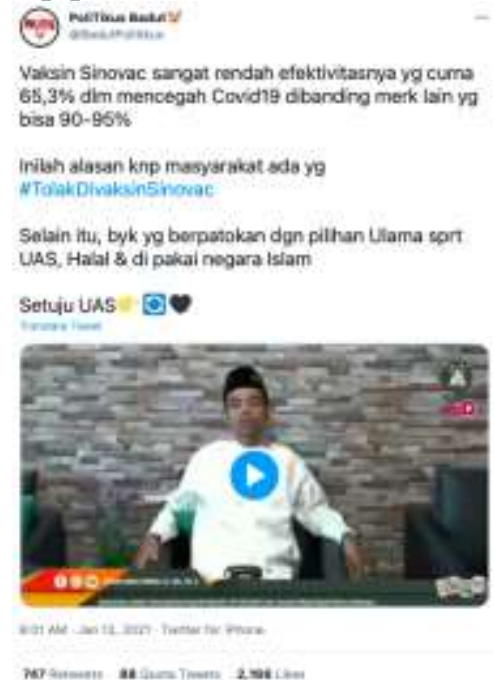

Gambar 0.3 Tangkapan layar kicauan dengan tagar \#TolakDivaksinSinovac

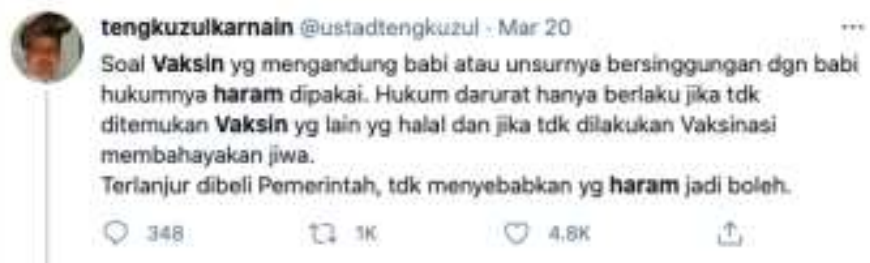

Gambar 0.4: Tangkapan layar kicauan kontroversi halal haram vaksin Sinovac

Selain respons negatif, di Twitter dapat diamati kicauan yang positif berkaitan dengan penggunaan vaksin Sinovac. Hal ini dapat dilihat dari salah satu kicauan akun @ ferdiriva yang menjelaskan data terbaru terkait efektivitas vaksin Sinovac dalam menangani COVID-19 (Gambar I.6). Selain itu, akun @ Cintada16 mencuit tentang opini terkait status halal haram vaksin Sinovac, namun ia tidak mempermasalahkan terkait status tersebut.

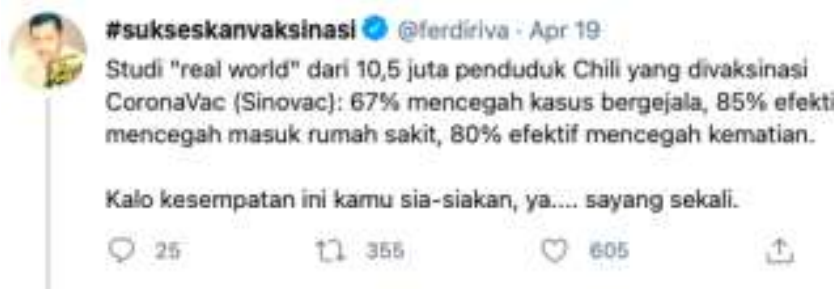

Gambar 0.5: Tangkapan layar kicauan terkait efektivitas vaksin Sinovac di Twitter 
LALA —Cintada16·Jan 12

"MUI Rilis Fatwa Halal Vaksin Sinovac".

Akhirnya..... kalau haram menurut MUI aku mah tetep mau suntik.

Suntik ya suntik... bantu Presiden Jokowi lawan Pandemi demi Indonesia.

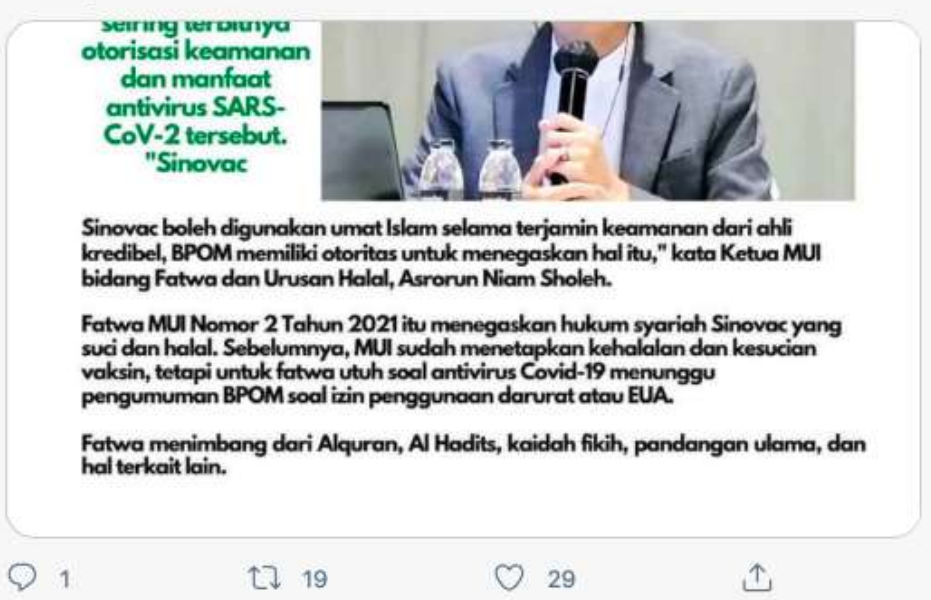

Gambar 0.6: Tangkapan layar kicauan terkait status halal vaksin Sinovac.

Beragam informasi yang ada di Twitter bisa saja berupa fakta ataupun sebaliknya. Apalagi ditengah masa krisis seperti saat ini dimana ketidakpastian adalah sesuatu yang perlu di hadapi secara bijak. Apalagi banyaknya informasi yang berseliweran di media sosial cukup sulit untuk diidentifikasi apakah informasi tersebut adalah fakta atau suatu kebohongan. Apalagi menurut laporan katadata (2020) yang mana pada level sub indeks literasi informasi masyarakat Indonesia masih terbilang rendah (Katadata, 2020). Hal ini kemudian dapat menjelaskan bagaimana dengan mudahnya suatu informasi dapat disebarkan melalui berbagai platform media sosial yang tersedia.

Informasi tersebut berpotensi dapat mempengaruhi persepsi masyarakat dalam menanggapi informasi yang beredar di Twitter terkait dengan efektivitas vaksin (Gruzd \& Mai, 2020). Apalagi dengan adanya peran buzzer yang terkesan mendukung hingga membela secara membabi buta kebijakan pemerintah dari kritikan pengguna lain dengan cara yang kontra-produktif dapat berpotensi membentuk polarisasi informasi di masa pandemi (Pambudi et al., 2021). Padahal dimasa krisis seperti saat ini idealnya masyarakat harus menyamakan persepsi dan bekerjasama untuk keluar dari pandemi. Namun tidak dapat dipungkiri bahwa kehadiran internet saat ini membuat arus informasi saat ini sangat sulit dibendung. Sehingga untuk menyikapi hal tersebut idealnya masyarakat sebagai pengguna media sosial perlu kritis terhadap setiap informasi yang mereka konsumsi.

Namun, faktanya para pengguna Twitter justru secara selektif mengonsumsi informasi yang sesuai dengan preferensi yang sifatnya subjektif. Contohnya dapat dilihat perilaku seseorang memilih secara selektif siapa saja orang yang akan diikuti. Hal ini terjadi karena adanya kecenderungan dalam memilih informasi untuk memperkuat pendapat-sembari menghindari informasi atau pendapat yang berbeda. Fenomena ini kemudian dikenal dengan sebutan terpaan selektif (selective exposure). Teori disonansi kognitif yang diajukan oleh Festinger serta Teori Uses and Gratification sering digunakan untuk memahami fenomena ini.

Adapun motif dari terpaan selektif ini tidak terlepas dari peran media partisan. Selain itu adanya faktor seperti siapa (who) yang menyampaikan pesan dan kondisi tertentu juga turut mempengaruhi sikap seseorang dalam mengonsumsi suatu informasi (Prior, 2013) dan adanya konsekuensi yang menguntungkan dari informasi yang dipilih juga turut berkontribusi terhadap motif terpaan selektif (Knobloch-Westerwick \& Meng, 2011).

Selain itu, adanya fitur-fitur penyedia layanan digital yang memungkinkan adanya personalisasi dapat memungkinkan algoritma bekerja untuk merekomendasikan suatu informasi 
berdasarkan hal yang disukainya, orang yang diikuti, berita yang terakhir dibaca, dan beragam bentuk personalisasi lainnya. Hal ini dikenal dengan istilah filter buble.

Terdapat beberapa penelitian terdahulu terkait fenomena terpaan selektif. Pertama, penelitian yang dilakukan oleh Knobloch dkk (2013) yang membahas tentang keberhasilan kampanye pesan kesehatan yang turut dipengaruhi oleh faktor kepercayaan atau kebiasaan yang dimiliki individu (Knobloch-Westerwick et al., 2013). Kedua, penelitian yang dilakukan oleh Prastyo dkk (2019) yang mempelajari kaitan antara disonansi kognitif dan terpaan selektif di kalangan wanita Pekerja Seks Komersial (PSK) (Prastyo et al., 2019). Ketiga, Anggarini (2020) yang meneliti terkait pilihan sumber informasi informan yang dipengaruhi oleh kebutuhan dan keinginan $(U \& G$ Theory) dalam mendapatkan informasi terkait COVID-19 (Anggarini, 2020). Keempat, Himelboim dkk (2020) yang meneliti terkait jaringan percakapan yang terjadi di Twitter terkait vaksin human papillomavirus (HPV) (Himelboim et al., 2020). Jaringan informasi kemudian membentuk suatu kluster yang ini akan digunakan untuk menganalisis aliran interaksi serta informasi yang dapat diimplementasikan dalam mempelajari terpaan selektif (Gambar 6).

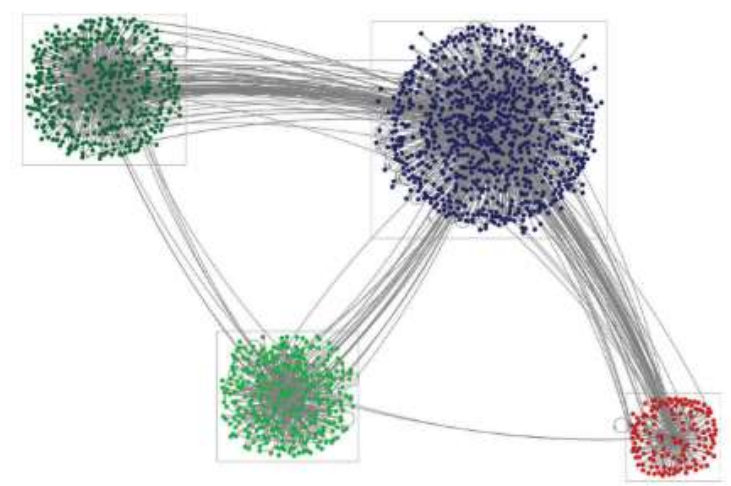

Gambar 0.7. Jaringan percakapan di Twitter yang divisualisasi dalam bentuk kluster

Berbeda dengan penelitian sebelumnya, penelitian ini menggunakan kluster sebagai level analisis dalam menganalisis aliran informasi di Twitter terkait dengan Vaksin Sinovac. Hal ini berbeda dengan penelitian yang dilakukan oleh Knobloch dkk (2013), Prastyo dkk (2019), dan Anggarini (2020) yang menggunakan individu sebagai level analisis dalam memahami terpaan selektif. Selanjutnya, penelitian ini memiliki beberapa kemiripan dengan penelitian yang dilakukan oleh Himelboim dkk (2020) yang menggunakan kluster untuk menganalisis terpaan selektif. Namun, berbeda dengan rencana penelitian yang akan dilakukan, peneliti akan menggunakan data digital pengguna Twitter di Indonesia. Selain itu, penelitian terdahulu terkait terpaan selektif yang dilakukan, khususnya di Indonesia masih menggunakan metode tradisional di mana metode seperti survei, eksperimen, dan wawancara merupakan metode yang lazim digunakan dalam mempelajari fenomena ini. Namun, seiring dengan perkembangan teknologi informasi dan komunikasi seperti media sosial, pendekatan metode tradisional menemui beberapa kendala dalam mengelola dan menganalisis data media sosial (data digital). Hal ini karena data digital (Big Data) menurut Laney memiliki tiga karakteristik, yaitu volume, velocity, dan variety sehingga membutuhkan pendekatan lain (Kitchin \& McArdle, 2016). Berangkat dari hal tersebut maka rencana penelitian akan menggunakan pendekatan big data yang akan dirangkaikan dengan analisis jaringan sosial (Social Network Analysis - SNA) sebagai basis metode dalam menganalisis terpaan selektif yang terjadi di Twitter. Analisis jaringan sosial sendiri adalah penerapan bidang ilmu jaringan yang diterapkan untuk mempelajari hubungan dan koneksi manusia (Hansen et al., 2011).

Secara umum terpaan selektif dapat diartikan sebagai fenomena di mana orang yang secara sengaja mencari informasi yang dapat mendukung atau memperkuat keyakinan sebelumnya, dan menghindari informasi yang bertentangan dengan pendapatnya (Freedman \& Sears, 1965). Menurut Festinger (1957) terpaan selektif menjadi proposisi sentral dalam teori disonansi kognitif (Festinger, 1957). Disonansi kognitif adalah perasaan tidak nyaman saat menghadapi dua hal yang 
bertentangan secara kognitif, sehingga memotivasi seseorang untuk mengurangi disonansi tersebut serta menghindari hal yang dapat meningkatkan disonansi.

Menurut teori disonansi Festinger (1957) pemilihan informasi yang sepandangan dapat membantu orang mengurangi disonansi. Tetapi tidak semua pengalaman disonansi kognitif perlu dikurangi karena orang dapat melupakan pandangannya sementara. Namun, ketika dihadapkan pada disonansi sedang, menurut Festinger, maka terpaan selektif akan muncul. Selanjutnya Festinger (1964) menemukan bahwa kepercayaan diri yang tinggi akan menginspirasi terpaan selektif yang lebih kecil daripada orang yang kurang percaya diri (Festinger, 1968).

Di bidang komunikasi, terpaan selektif menjadi penjelasan umum mengapa para sarjana tidak menemukan lebih banyak bukti tentang kekuatan efek media. Berdasarkan hal ini, menurut Klapper dalam Freedman dan Sears (1965), terpaan selektif merupakan faktor penting dalam menentukan efektivitas komunikasi massa. Sehingga, masih menurut Klapper dalam Stroud (2014), media cenderung mengambil peran sebagai penguat sikap daripada pengubah sikap publik (Stroud, 2014). Selanjutnya menurut McGuire dan Papageorgis (1961) terpaan selektif adalah bentuk resistensi publik resistensi terhadap segala pesan persuasi yang diterima (McGuire \& Papageorgis, 1961). Dalam konteks pencarian informasi kesehatan secara daring, fenomena selektif eksposur juga muncul jika berbicara terkait penyakit berisiko tinggi. Pertentangan yang muncul dapat muncul dari perdebatan terkait efektivitas dan dampak kesehatan dari suatu pengobatan yang ditawarkan (Liao et al., 2015), dalam penelitian ini adalah penggunaan vaksin COVID-19 untuk penyakit COVID-19. Lauckner \& Hsieh dalam Liao (2015) menggunakan istilah "cyberchondria" untuk menggambarkan secara spesifik fenomena terpaan selektif yang terjadi dalam pencarian informasi kesehatan di dunia maya. Cyberchondria merujuk pada eskalasi masalah medis orang-orang setelah melakukan penelusuran informasi secara daring. Misalnya, mesin pencari (seperti Google) yang menggunakan algoritma untuk menyediakan informasi yang lebih "memuaskan" penggunanya dibanding memberikan informasi yang akurat. Hal ini dapat menyebabkan bias konfirmasi yang dapat mendukung kepercayaan sebelumnya. Lebih jauh lagi, kecenderungan yang didasari oleh adanya ketidakpastian dapat mengarah pada keputusan medis yang kurang akurat.

Terdapat beberapa alasan mengapa penelitian ini perlu dilakukan. Pertama, infodemik merupakan tantangan bagi keberhasilan pemerintah dan masyarakat dalam menangani penyebaran virus COVID-19. Kedua, perkembangan informasi terkait vaksin Sinovac yang masih terus berkembang menuntut pemerintah dan segenap pemangku kepentingan untuk lebih responsif terhadap perkembangan opini publik. Ketiga, menjaga kepercayaan publik dan peningkatan efikasi diri merupakan prioritas utama sehingga pemerintah memiliki peran dalam mengintervensi perilaku kesehatan masyarakat.

Dengan memahami jaringan informasi yang terbentuk, maka penelitian dapat memberikan visualisasi kluster. Setiap kluster merupakan representasi dari adanya diskursus publik yang terjadi. Dengan menganalisis kluster maka dapat diketahui siapakah aktor kunci dalam suatu jaringan.

Berangkat dari permasalahan tersebut, peneliti akan menggunakan data Twitter sebagai basis data dalam menganalisis adanya fenomena terpaan selektif terkait topik vaksin COVID-19. Pemilihan media sosial Twitter karena kemudahan akses, hal ini dimungkinkan sebab adanya fitur Twitter API, serta akun pengguna Twitter yang secara default adalah akun publik. Selanjutnya, jumlah pengguna dan lalu lintas yang tinggi memungkinkan penelitian ini dilakukan dalam skala besar (nasional). Apalagi pada kondisi pandemi saat ini penelitian lapangan tidak dapat dilakukan karena adanya pembatasan sosial (interaksi langsung). Fokus permalahan adalah bagaimana pengguna Twiter emmbentuk kluster yang berbeda saat berkontribusi dalam diskusi terkait vaksin COVID-19 di Twiter. Dengan demikian tujuan penelitian adalah mengidentifikasi kluster yang terbentuk dalam jaringan Twitter terkait dengan topik vaksin Covid-1 
AKSARA: Jurnal Ilmu Pendidikan Nonformal

P-ISSN 2407-8018 E-ISSN 2721-7310 DOI prefix 10.37905

Volume 08, (1), January 2022

http://ejurnal.pps.ung.ac.id/index.php/Aksara

\section{METODE PENELITIAN}

Penelitian ini menggunakan metode kuantitatif dengan menggunakan pendekatan analisis jaringan sosial serta pendekatan big data. Selanjutnya, metode ini akan disebutkan sebagai metode kluster terpaan selektif. Penelitian ini bertujuan untuk mengidentifikasi sub-kelompok yang terbentuk terkait topik vaksin COVID-19 di Twitter, mengidentifikasi hub dalam suatu subkelompok, serta untuk mengetahui jumlah frekuensi penggunaan tagar, hyperlink, dan mention dari masing-masing sub-kelompok. Penelitian ini akan menggunakan data media sosial Twitter sebagai data primer untuk dianalisis. Untuk mengumpulkan data tersebut serta menganalisisnya maka akan digunakan perangkat lunak NodeXL.

Lokasi dan Batasan Waktu Penelitian

Dikarenakan basis data yang digunakan adalah data media sosial. Maka lokasi penelitian yang dimaksud oleh peneliti adalah Twitter. Alasan memilih Twitter karena adanya fitur Twitter API sehingga memungkinkan peneliti untuk mengekstrak data publik Twitter.

Untuk pengambilan data dilakukan dalam dua sesi, yaitu sesi pertama mengambil data yang dibatasi pada tanggal 13-14 November 2021 dan sesi kedua pada tanggal 15-16 November 2021 dengan menggunakan kata kunci vaksinasi. Namun, jika selama proses penelitian terdapat momen tertentu terkait vaksin COVID-19 maka peneliti dapat menambahkannya kemudian.

Populasi dan Sampel

Populasi adalah wilayah generalisasi yang terdiri atas objek atau subjek yang mempunyai kualitas dan karakteristik tertentu yang ditetapkan oleh peneliti untuk dipelajari dan kemudian ditarik kesimpulannya. Namun, berbeda dengan penelitian tradisional yang lazim menarik sampel dari populasi yang akan diteliti. Penelitian big data menggunakan seluruh populasi atau sistem $(\mathrm{n}=\mathrm{all})$ untuk menarik kesimpulan suatu fenomena yang terjadi dalam suatu populasi (Kitchin, 2014).

Selanjutnya, metode yang akan digunakan tidak mensyaratkan adanya penarikan sampel karena penelitian ini akan menarik kesimpulan berdasarkan populasi atau sistem yang berhasil di dapatkan. Sehingga kesimpulan yang didapatkan tidak dapat digunakan serta merta untuk menggeneralisir fenomena selektif eksposur di masyarakat (kondisi riil). Sehingga diperlukan penelitian yang lebih lanjut untuk memverifikasi temuan penelitian ini.

Selain itu, karena unit analisis dari metode kluster terpaan selektif ini adalah kluster maka populasi dari penelitian ini adalah jaringan sosial yang terbentuk berdasarkan kicauan dari kata kunci "Vaksin COVID-19" dan "Vaksin Korona"(Himelboim et al., 2013).

Data primer yang akan digunakan adalah data media sosial Twitter maka diperlukan perangkat lunak khusus yang dapat mengumpulkan serta menganalisis data tersebut. Untuk itu peneliti akan menggunakan perangkat lunak NodeXL Pro versi 1.0.1.447 pada komputer berkapasitas 12 GB (RAM). Dengan spesifikasi RAM sebesar ini memungkinkan peneliti untuk mengambil kumpulan data dalam jumlah yang besar. Penggunaan perangkat ini memungkinkan peneliti untuk mengumpulkan big data dan menganalisisnya.

Karakteristik big data yang tidak dapat dianalisis dengan teknik analisis tradisional, seperti uji statistik, mengharuskan penggunaan perangkat lunak tertentu seperti NodeXL. Selanjutnya, peneliti di sini akan bertindak sebagai human content coders untuk mengidentifikasi dan memaknai hasil analisis data. NodeXL akan digunakan untuk mengumpulkan data serta untuk melakukan analisis yang dapat membantu menjawab pertanyaan-pertanyaan penelitian terkait kluster, hub, dan frekuensi penggunaan dan sharing sumber informasi.

Sebelum menggunakan metode kluster terpaan selektif peneliti perlu mengumpulkan data berdasarkan jaringan topik yang ingin diteliti dengan menggunakan NodeXL. Selanjutnya, peneliti akan menggunakan kata kunci vaksinasi untuk menangkap percakapan terkait vaksin COVID-19 di Twitter. Peneliti akan mengambil tipe hubungan antar pengguna Twitter berdasarkan mentions, replies, dan follows. Peneliti kemudian akan memilih pilihan untuk menghindari pengumpulan data yang tidak berkaitan dengan kata kunci yang akan digunakan. Setelah itu, peneliti akan mengambil kicauan pengguna Twitter untuk dianalisis pesan yang ada 
dalam suatu kicauan. Terakhir peneliti akan mengaktifkan fitur "expand URL in Tweets" agar peneliti dapat melihat halaman asli dari url website yang telah diperpendek.

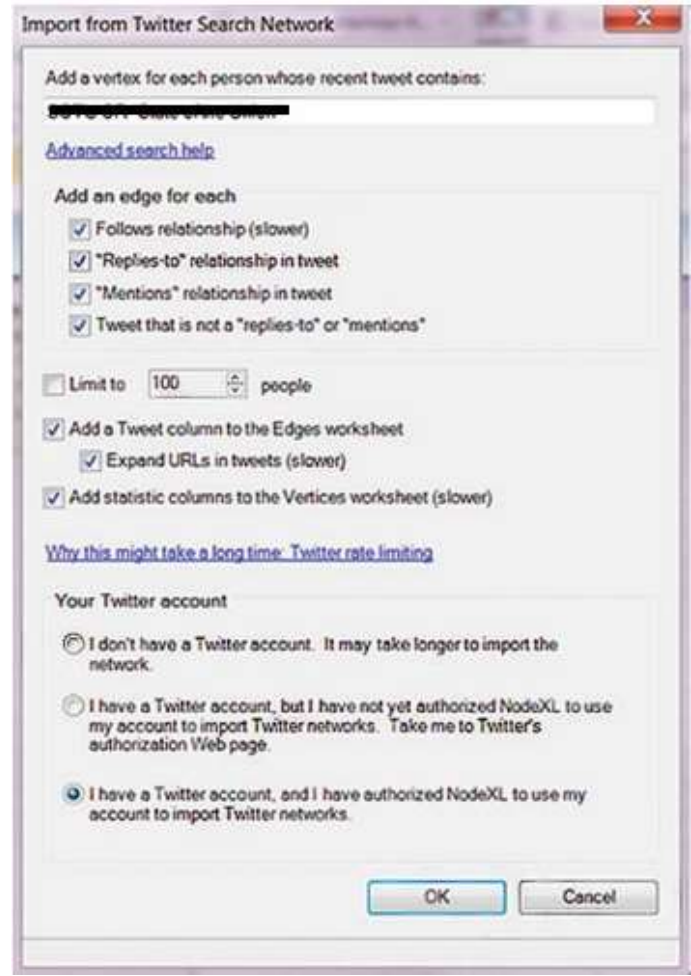

\section{Gambar 0.8 Mengimport data Twitter}

Metode kluster terpaan selektif digunakan untuk menangkap fenomena terpaan selektif pada jaringan sosial yang terbentuk di Twitter. Untuk itu, data yang telah berhasil dikumpulkan akan dianalisis dengan cara mengelompokkan berdasarkan kluster algoritma Clauset-Newman-Moore. Untuk membuat matriks jaringan maka pada pilihan Graph Metrics peneliti akan memilih beberapa matriks perhitungan, yaitu:

1. Overall graph metrics: menghitung statistik seluruh jaringan, termasuk modularitas, mengukur kualitas kluster berdasarkan algoritma.

2. Vertex In-Degree: digunakan untuk mengidentifikasi hub dalam suatu kluster berdasarkan jumlah pengguna yang mengikutinya, menyebutkannya, dan membalas kicauannya. Pengukuran ini digunakan untuk menangkap aktivitas sosial di mana akan memberikan indikasi seberapa menonjol setiap pengguna dalam eksposur terhadap konten yang diposting oleh $h u b$.

3. Group metrics: menghitung berbagai pengukuran khusus kluster, termasuk jumlah pengguna dan hubungan di setiap kluster. Informasi ini digunakan untuk mengidentifikasi kluster teratas (dominan).

4. Twitter search network top items: menghitung frekuensi tagar, hyperlink, dan mention @ username yang paling sering digunakan dalam kicauan yang berhasil dikumpulkan. 


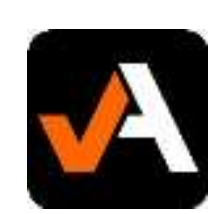

AKSARA: Jurnal Ilmu Pendidikan Nonformal

P-ISSN 2407-8018 E-ISSN 2721-7310 DOI prefix $\underline{10.37905}$

Volume 08, (1), January 2022

http://ejurnal.pps.ung.ac.id/index.php/Aksara

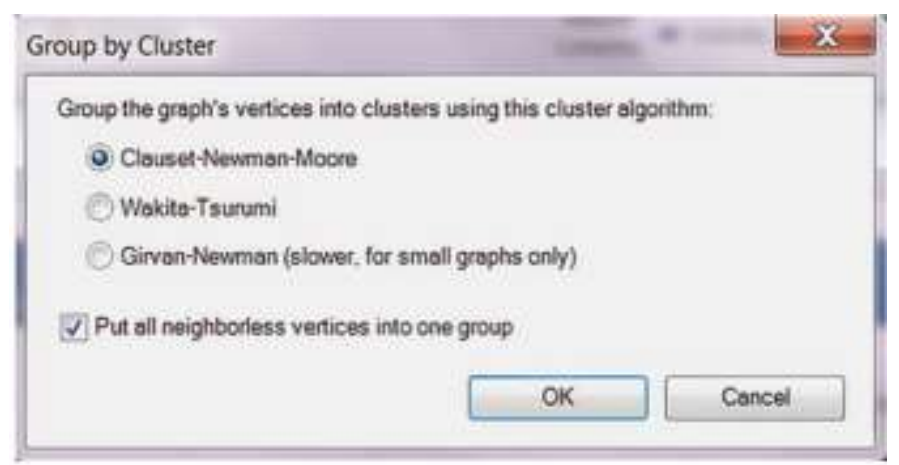

Gambar 0.9 Analisis kluster

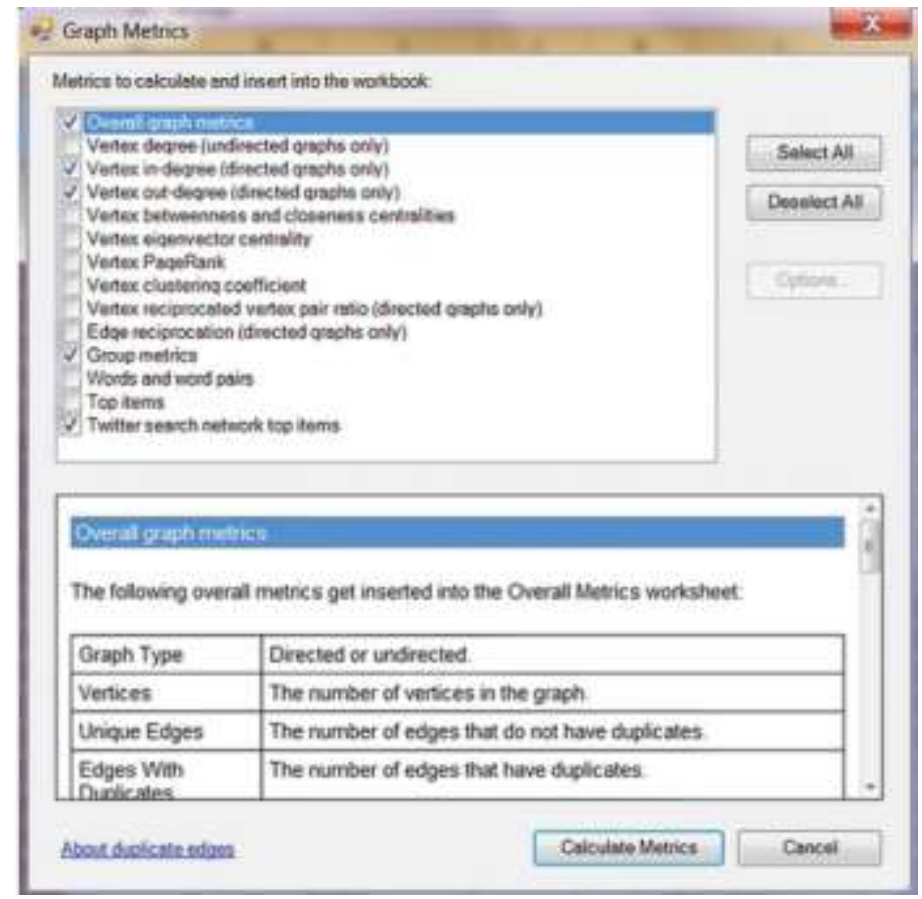

Gambar 0.10 Analisis jaringan

Setelah kluster berhasil diidentifikasi maka akan diadakan pengukuran modularitas untuk meninjau kualitas pembagian atau jarak antar-kluster dalam populasi jaringan. Modularitas digunakan untuk mengukur sejauh mana pembagian antar-kluster. Nilai modularitas berkisar pada angka nol dan satu. Jadi, semakin tinggi nilai modularitas maka semakin berbeda atau terpisah tiap-tiap kluster. Selanjutnya ambang batas yang ditetapkan dapat digunakan untuk mengukur modularitas antar-kluster. Berikut ambang batas yang akan digunakan adalah sebagai berikut:

- $0,6=$ ambang batas modularitas tinggi

- $0,4=$ ambang batas modularitas menengah

Berdasarkan ambang batas di atas maka:

- Nilai modularitas yang lebih kecil dari $0,4(<0,4)$ dianggap jarak (perpisahan) antarkluster adalah rendah (tidak terlalu terpisah).

- Nilai modularitas antara 0,4 dan 0,6 $(0,4-0,6)$ dianggap jarak antar-kluster adalah sedang.

- Nilai modularitas di atas 0,6 $(>0,6)$ dianggap jarak antar-kluster adalah tinggi (sangat terpisah).

Jaringan antar-kluster yang sangat terpisah (modularitas tinggi) dapat menunjukkan terpaan selektif yang lebih tinggi, artinya pengguna di dalam kluster tersebut lebih terekspos satu sama lain dan lebih sedikit terpapar konten dari pengguna lain yang berada di luar klusternya. 


\section{HASIL PENELITIAN DAN PEMBAHASAN}

Gambaran Umum Media Sosial Twitter

Twitter merupakan salah satu media sosial berbasis microblogging yang memungkinkan penggunananya untuk melakukan "percakapan" asinkron berbasis web publik. Dimana para penggunannya dapat mengirimkan pesan sebanyak 280 karakter ditiap kicauannya (Murthy, 2013). Konten pengguna (user-generated content) yang dikirimkan melalui media Twitter pada umumnya dapat kirimkan melalui berbagai perangkat komunikasi seperti smartphone dan komputer. Twitter sendiri pertama kali diperkenalkan ke publik pada bulan Juli tahun 2006 oleh Jack Dorsey, Biz Stone, dan Evan Williams.

Selanjutnya, setiap kicauan pengguna akan terposting otomatis di halaman profil pengguna Twitter. Berbeda dengan Facebook, setiap postingan di Twitter dapat diakses oleh publik walaupun tidak ada hubungan pertemanan/mengikuti. Di Facebook setiap postingan hanya dibatasi oleh mereka yang telah masuk kedalam daftar pertemanan. Hal ini kemudian yang membedakan fungsi update status diantara kedua sosial media ini, dimana setiap postingan di Twitter dikondisikan agar memantik kesadaran publik bagi seluruh penggunanya.

Selanjutnya pengguna memiliki kesempatan yang sama untuk dapat melakukan dialog terhadap pengguna Twitter lainnya. Contohnya, kita dapat memulai percakapan ke akun Twitter Presiden Indonesia dengan mengetikkan “@jokowi” pada pesan yang akan kita tulis, istilah ini dikenal dengan nama mention. Selain itu, setiap orang dapat melihat kicauan seseorang dan memberikan tanggapan terhadap kicauan itu. Hal ini dapat dilakukan tanpa harus mengenal satu sama lain atau tidak perlu mendapatkan persetujuan dari pengguna lain agar bisa melakukan mention@username.

Twitter sering digunakan oleh beberapa penggunanya untuk menyatakan perasaannya, sedangkan lainnya menggunakan Twitter untuk kepentingan komunitas, dan bahkan untuk sekedar mencari teman kencan dengan cara yang instan. Namun seiring perkembangan zaman Twitter sebagai media komunikasi juga kerap digunakan untuk melancarkan agenda bermotif politik dan ekonomi, serta juga kerap digunakan untuk menggerakkan massa serta mencari dukungan sebagai mana dapat dilihat dari fenomena Arab Spring dan tagar \#BlackLiveMaters.

Kepopuleran Twitter tidak terlepas dari adanya faktor kemudahannya (ease of use). Kemudahan penggunaan ini dapat disimpulkan kedalam beberapa poin berikut:

1. Kepemilikan smartphone yang sudah hampir merata memungkinkan tiap orang untuk berkicau di Twitter.

2. Para pengguna smartphone sudah familiar dengan konsep texting dimana sebelum ada Twitter para pengguna sudah terbiasa dengan SMS atau Chat (BBM, mIRC, Yahoo Mesengger). Jadi para pengguna Twitter hanya perlu sedikit mengeluarkan usaha untuk mempelajari Twitter.

3. Twitter dapat diakses walau dengan koneksi internet yang terbatas atau lambat.

4. User interface yang sederhana namun efektif penggunaannya.

Walaupun terlihat sederhana Twitter justru medium ini menawarkan sesuatu yang lebih (powerfull). Hal ini karena setiap kicauan yang dibuat oleh pengguna dapat menghubungkan pada tema yang lebih besar misalnya melalui fungsi tagar. Tagar sendiri merupakan bagian integral dari Twitter yang memungkinkan terjadinya koneksi percakapan diantara orang-orang lain secara bersama-sama. Misalnya penggunaan tagar \#SayaSiapDivaksin yang digunakan untuk merujuk pada even tertentu. Adanya penggunaan tagar ini memungkinkan suatu kicauan dapat masuk kedalam jaringan percakapan yang lebih besar. Stuktur komunikasi dengan menggunakan tagar memungkinkan terjadinya interaksi antar individu (lebih sering dengan orang asing).

\section{Tampilan Antarmuka Twitter}

Twitter oleh penggunanya dapat diakses melalui komputer atau smartphone. Pada bagian ini akan dideskripsikan secara rinci terkait tampilan antarmuka pengguna (user interface) yang dibagi menurut tampilan di web dan aplikasi Twitter di smartphone. Untuk dapat mengakses halaman website Twitter dengan menggunakan komputer maka pengguna perlu menjalankan dulu 
aplikasi browsing (chrome, mozila, edge, safari). Setelah itu pengguna dapat mengetikkan alamat url www.twitter.com agar dapat memasuki Twitter. Agar dapat mengakses Twitter di smartphone pengguna dapat menggunakan browser yang tersedia dan memasukkan url www.twitter.com. Namun banyak dari pengguna smartphone memasang aplikasi Twitter yang dapat di unduh melalui App store (Apple) dan Play Store (Android).

Ketika pengguna ingin mengakses Twitter baik melalui komputer atau smartphone. Maka secara default kita akan memasuki halaman log in dan/atau sign up. Jika sudah memiliki akun maka hanya perlu mengklik tombol log in namun jika belum maka kita perlu melakukan registrasi yang cukup mudah agar bisa memiliki akun Twitter. Setelah log in maka tampilan antarmuka akan terlihat seperti pada gambar dibawah ini.

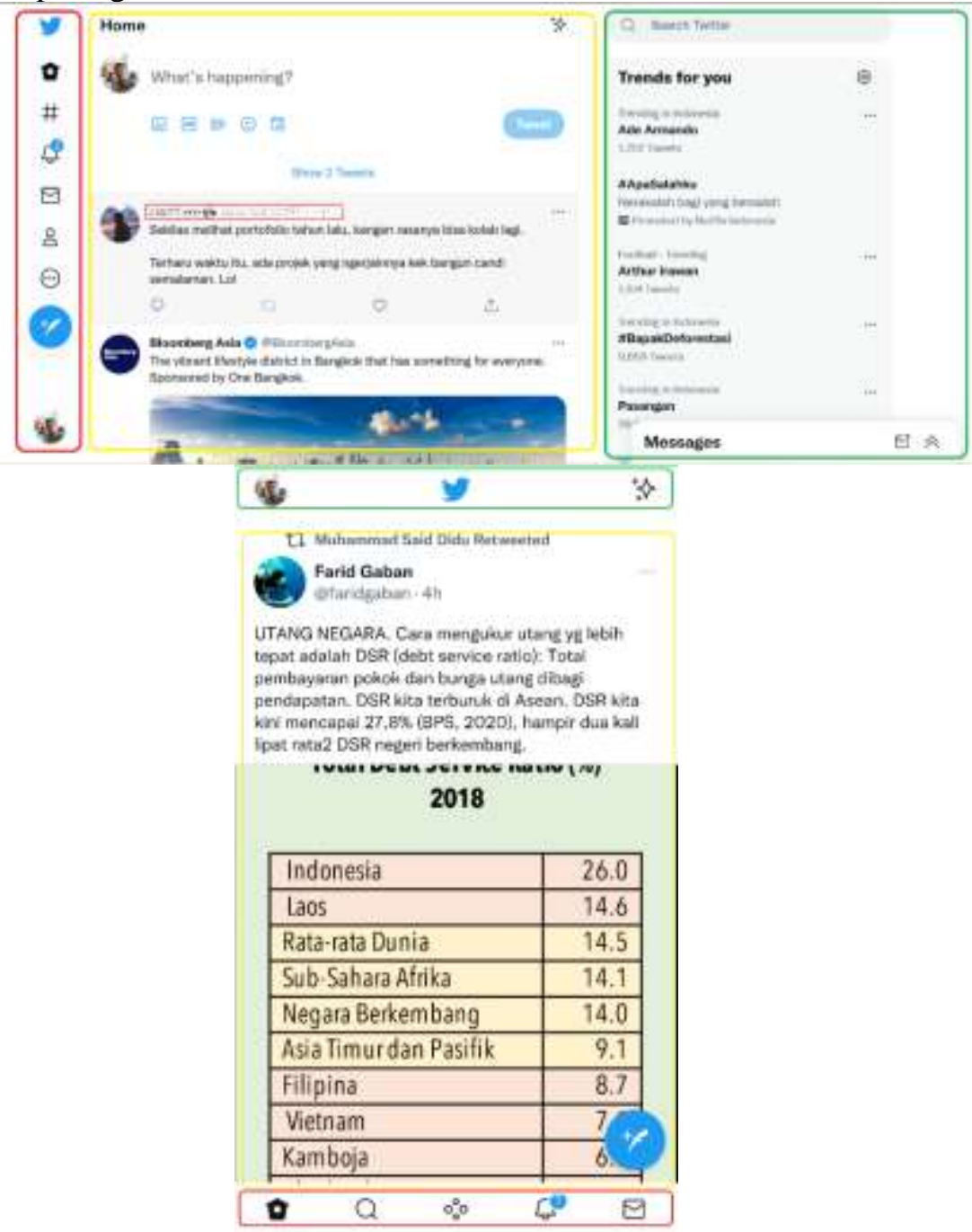

Gambar 011. Tampilan antar muka twiter

Seperti yang terlihat dari kedua tampilan antarmuka di atas dapat dibagi menjadi tiga bagian. Dimana bagian pertama adalah navigasi (kotak merah) dimana pada tampilan website kontrol navigasi ini terletak pada sisi kiri halaman sedangkan dari tampilan aplikasi kontrol navigasi terletak pada bagian bawah. Kedua, bagian inti (kotak kuning) dimana dibagian ini menampilkan feed dari pengguna, topik, atau list yang mereka ikuti. Bagian ketiga (kotak hijau) dapat dilihat ada sedikit perbedaan dari tampilan antarpenggunanya. Pada tampilan website bagian ini dapat diidentifikasi sebagai bagian eksplorasi sedangkan pada tampilan aplikasi bagian ini dapat diidentifikasi sebagai navigasi ekstra dimana memiliki fungsi-fungsi lain yang dapat digunakan oleh pengguna. 
Pada halaman website Twitter maupun aplikasi dapat diidentifikasi beberapa tombol navigasi yang memiliki fungsinya masing-masing. Hal ini akan dijabarkan secara singkat ke dalam beberapa poin sebagai berikut.

\begin{tabular}{|c|c|c|}
\hline Logo & Nama & Deskripsi \\
\hline & $\begin{array}{l}\text { Home } \\
\text { (website dan } \\
\text { aplikasi) }\end{array}$ & $\begin{array}{l}\text { Tombol navigasi yang akan membawa pengguna menuju halaman } \\
\text { utama Twitter. Halam utama ini berisi feed yang terupdate secara } \\
\text { real time. }\end{array}$ \\
\hline & $\begin{array}{l}\text { Explore } \\
\text { (website dan } \\
\text { aplikasi) }\end{array}$ & $\begin{array}{l}\text { Tombol navigasi yang akan membawa pengguna menuju halaman } \\
\text { eksplorasi. Halaman ini berisi berita, trending topik, kejadian } \\
\text { terkini, dan topik yang diikuti. }\end{array}$ \\
\hline & $\begin{array}{l}\text { Notification } \\
\text { (website dan } \\
\text { aplikasi) }\end{array}$ & $\begin{array}{l}\text { Tombol navigasi yang akan membawa pengguna menuju halaman } \\
\text { yang berisi notifikasi. Notifikasi dibagi menjadi dua bagian, yaitu } \\
\text { All dan Mentions. Untuk All yang ditampilkan dapat berupa kicauan } \\
\text { terbaru atau yang terlewatkan dari pengguna yang kita ikuti, serta } \\
\text { kicauan yang direkomendasikan. Untuk mentions berisi notifikasi } \\
\text { dari interaksi yang disebabkan oleh mention, reply, dan retweet. }\end{array}$ \\
\hline & $\begin{array}{l}\text { Messages } \\
\text { (website dan } \\
\text { aplikasi) }\end{array}$ & $\begin{array}{l}\text { Tombol navigasi yang akan membawa pengguna menuju halaman } \\
\text { pesan. Halaman ini fungsinya hampir sama dengan fitur inbox yang } \\
\text { dimiliki oleh Facebook dan fitur Direct Messages yang dimiliki } \\
\text { oleh Instagram. Adanya fitur ini memungkinkan masing-masing } \\
\text { pengguna untuk dapat mengirimkan pesan secara privat. }\end{array}$ \\
\hline & $\begin{array}{l}\text { Profile (hanya di } \\
\text { website) }\end{array}$ & $\begin{array}{l}\text { Tombol navigasi ini akan membawa penggunanya ke halaman } \\
\text { profil pengguna. Di halaman ini berisi avatar (foto profil) pengguna, } \\
\text { nama akun, bio, tanggal bergabung, jumlah following dan followers, } \\
\text { tweets, media, dan like. Halaman profil ini juga akan ditampilkan } \\
\text { jika kita mengakses profil pengguna lain namun bagi akun yang } \\
\text { diatur ke akun privat maka pengguna lain dapat melihat konten yang } \\
\text { berada di profilnya jika sudah mengikuti tersebut. }\end{array}$ \\
\hline & $\begin{array}{l}\text { More (hanya di } \\
\text { website) }\end{array}$ & $\begin{array}{l}\text { Tombol navigasi ini jika diklik akan memunculkan jendela pop up } \\
\text { yang akan menampilkan pilihan navigasi yang memiliki fungsi } \\
\text { masing-masing. Di dalamnya kita dapat melihat fitur bookmarks, } \\
\text { list, topik, momen, newsletters, Twitter for Professional, Twitter } \\
\text { Ads, Analytics, pengaturan dan privasi, pusat bantuan, tampilan, dan } \\
\text { pintasan keyboard. }\end{array}$ \\
\hline & $\begin{array}{l}\text { Tweet (website } \\
\text { dan aplikasi) }\end{array}$ & $\begin{array}{l}\text { Tombol navigasi yang akan membawa pengguna langsung menuju } \\
\text { halaman pembuatan pesan (kicauan). Jika kita menekan tombol ini } \\
\text { ketika sedang melihat akun pengguna lain maka secara otomatis } \\
\text { akan disebut (mentions) kedalam pesan yang akan kita tulis. }\end{array}$ \\
\hline & $\begin{array}{l}\text { Accounts } \\
\text { (website dan } \\
\text { aplikasi) }\end{array}$ & $\begin{array}{l}\text { Tombol navigasi ini akan memunculkan pop up window dimana } \\
\text { terdapat pilihan menambahkan akun lain dan pilihan keluar dari } \\
\text { akun. Namun di aplikasi tombol ini akan memunculkun beragam } \\
\text { fitur lain seperti yang terdapat pada tombol navigasi more pada } \\
\text { website. }\end{array}$ \\
\hline
\end{tabular}

Tabel 01 Tombol Navigasi Twiter

\section{Pembentukan Kluster dalam Hubungan Sosial di Twitter}

Fungsi dari mengikuti di Twitter dalam beberapa hal mengikuti fungsi televisi, dimana di televisi kita dapat melihat beragam pilihan saluran yang ada. Jika saluran televisi itu menarik perhatian kita maka kita dapat terus berada di saluran itu. Di Twitter hal ini juga terjadi, dimana ketika pengguna memutuskan untuk mengikuti timelines dari pengguna lain (selebriti/a, teman, tetangga, organisasi professional, media massa, perusahasan, dan lain sebagainya. Adanya hubungan mengikuti dan diikuti ini turut membentuk konsumsi kicauan berdasarkan akun yang mereka ikut. Berbeda dengan Facebook dimana menggunakan istilah teman, para pengguna Twitter tidak perlu saling mengenal satu sama lain (secara langsung) untuk dapat mengikuti satu sama lain. Hal ini kemudian memiliki hubungan terhadap terbentuknya struktur asinkron. Dimana terdapat beberapa yang lebih popular dibandingkan dengan akun-akun lain. 
Berbeda dengan penyiaran pesan yang dilakukan oleh televisi dan radio (one to many broadcasting) misalnya, Twitter dibangun berdasarkan desain penyiaran pesan yang interactive multicasting (penyiaran pesan dari many to many) (Murthy, 2013). Misalnya dengan menggunakan fungsi tagar dan retweets dapat memungkinkan terjadinya model penyiaran many to many. Retweet (RT) sendiri adalah fungsi yang memungkinkan orang untuk "meneruskan" pesan tertentu kepada para pengikutnya dan ini memungkinkan terjadinya redistribusi pesan hingga keluar dari jaringan sempit ke jaringan yang lebih luas. Contohnya, jika seorang pengguna me-retweet kicauan akun tertentu maka kicauan itu dapat dilihat oleh pengikutnya walaupun pengikutnya tersebut tidak mengikuti akun dari kicauan yang di-retweet. Hal ini kemudian menurut Himelboim dkk (2013) yang disebut dengan hubungan yang tidak langsung (indirect relationship).

Mekanisme kerja Twitter inilah yang memungkinkan pengguna lain untuk memberi perhatian terhadap suatu pesan. Apalagi jika konten tersebut di-retweet oleh banyak orang atau oleh orang yang tepat (influencer) biasanya konten tersebut akan menciptakan momentum yang dapat menimbulkan efek bola salju.

Tagar sendiri adalah simbol yang dapat menggambarkan adanya interactive multicasting di mana banyak pengguna menyiarkan ke banyak pengguna lain terkait topik yang diberikan tagar. Contohnya, adanya penggunaan tagar \#SayaSiapDivaksin dan \#TolakDivaksinSinovac pada momentum awal persemian program vaksinasi nasional di Indonesia. Selain itu hal menarik lainnya, pengguna dapat memasukkan konten multimedia (hyperlinks, foto, dan video) yang sesuai dengan topik tertentu. Berbeda dengan media massa konvensional seperti televisi, pengguna Twitter dapat secara aktif berselancar pada konten-konten yang tersedia di Twitter. Bahkan para pengguna tidak hanya menjadi aktor yang mengkonsumsi suatu konten di Twitter, mereka dapat menjadi produser jika mereka berkomentar pada konten asli atau menuliskan pesan balasan terhadap penyiar pertama.

Setelah melakukan proses pengumpulan set data maka peneliti berhasil mengumpulkan kicauan berdasarkan kata kunci "vaksinasi" yang berhubungan dengan percakapan terkait program vaksinasi COVID-19 di Indonesia. Untuk lebih jelasnya lihat tabel di bawah ini.

\begin{tabular}{|c|c|c|c|}
\hline Period & Vertices & $\begin{array}{c}\text { Maximum Vertices } \\
\text { in a Connected } \\
\text { Component }\end{array}$ & Unique Edges \\
\hline 13-14 November & 2.307 & 1.779 & 21.710 \\
\hline 15-16 November & 2.954 & 2.495 & 28.986 \\
\hline
\end{tabular}

Tabel 02 Kicauan vaksinasi covid-19

Berdasarkan tabel diatas jumlah total kumpulan data adalah 5.261 pengguna Twitter yang aktif berkontrobusi dalam percakapan terkait vaksin korona pada tanggal 13-16 November 2021. Pada sesi pertama (13-14 November 2021) terdapat kumpulan data yang terdiri dari 2.307 pengguna Twitter, dimana 1.779 diantaranya terhubung oleh 21.710 hubungan unik (seperti hubungan mengikuti, mention, atau membalas). Sedangkan pada sesi ke dua (15-16 November 2021) terdiri dari 2.954 pengguna, dimana 2.495 diantaranya terhubung oleh 28.986 hubungan unik.

Selanjutnya akan dilakukan pemetaan berdasarkan kumpulan data berdasarkan hubungan antarpengguna dan mengaplikasikan analsiis jaringan untuk mengidentifikasi kluster dan hub yang dapat digunakan untuk menjawab pertanyaan penelitian.

\section{Kluster}

Berdasarkan hasil analisis kluster dengan menggunakan algoritma Clauset-Newman-Moore, pada tanggal 13-14 November ditemukan dua kluster besar dimana kluster pertama terdiri dari 964 pengguna dengan 11.521 koneksi dan kluster kedua terdiri dari 449 pengguna dengan 7.539 koneksi. Kedua kluster utama ini menyumbang $79,4 \%$ dari seluruh pengguna yang terhubung dan 
$87,7 \%$ dari seluruh hubungan dalam jaringan. Nilai modularitas untuk kluster ini adalah 0,44 , angka ini menunjukkan tingkat pemisahan yang moderat di antara kluster.

Selanjutnya, jaringan yang terbentuk pada 15-16 November mengungkapkan dua kluster utama dimana kluster pertama terdiri dari 834 pengguna dengan 8.222 koneksi dan kluster kedua terdiri dari 660 pengguna dan 9.680 koneksi. Kedua kluster utama ini menyumbang 59,8\% dari semua pengguna yang terhubung dan $61,7 \%$ dari seluruh hubungan dalam jaringan. Nilai modularitas untuk jaringan ini adalah 0,43 dimana angka ini menunjukkan tingkat pemisahan yang moderat di antara kluster. Untuk lebih jelasnya lihat tabel dibawah ini.

\begin{tabular}{|c|c|c|c|c|c|c|}
\hline Period & $\begin{array}{l}\text { Cluster } \\
\text { Group }\end{array}$ & Vertices & $\begin{array}{l}\text { Unique } \\
\text { Edges }\end{array}$ & $\begin{array}{l}\text { Percentage } \\
\text { G1+G2 } \\
\text { Vertice in } \\
\text { Whole } \\
\text { Network }\end{array}$ & $\begin{array}{l}\text { Percentage } \\
\text { G1+G2 } \\
\text { Unique } \\
\text { Edges in } \\
\text { Whole } \\
\text { Network }\end{array}$ & $\begin{array}{c}\text { Modularity } \\
<0,4=\text { low } \\
0,4- \\
0,6=\text { moderate } \\
>0,6=\text { high }\end{array}$ \\
\hline \multirow{2}{*}{$\begin{array}{l}13-14 \\
\text { Nov }\end{array}$} & G1 & 964 & 11.521 & \multirow{2}{*}{$79,4 \%$} & \multirow{2}{*}{$87,7 \%$} & \multirow{2}{*}{0,44} \\
\hline & G2 & 449 & 7.539 & & & \\
\hline \multirow{2}{*}{$\begin{array}{l}15-16 \\
\text { Nov }\end{array}$} & G1 & 834 & 8.222 & \multirow{2}{*}{$59,8 \%$} & \multirow{2}{*}{$61,7 \%$} & \multirow{2}{*}{0,43} \\
\hline & G2 & 660 & 9.680 & & & \\
\hline
\end{tabular}

Tabel 03 Pembentukan kluster jaringan

Hub

Untuk mengidentifikasi hub (pengguna) dalam suatu kluster jaringan, maka akan dilakukan pengukuran tingkat keterhubungan dan posisi setiap pengguna dalam jaringan yang dihitung. Langkah-langkah ini mencakup pengukuran yang terdiri dari jumlah hubungan langsung antarpengguna (in-degree centrality). Maka berikut lima hub teratas untuk setiap kluster yang berhasil diidentifikasi.

\begin{tabular}{|c|c|c|c|}
\hline Periode & Kluster & Vertex & Deskripsi Singkat \\
\hline \multirow[t]{8}{*}{$\begin{array}{l}13-14 \\
\text { Nov }\end{array}$} & \multirow[t]{5}{*}{ Kluster G1 } & @jokowi & $\begin{array}{l}\text { "Akun Twitter resmi Presiden Republik } \\
\text { Indonesia Joko Widodo ID. } \\
\text { \#MenujuIndonesiaMaju" }\end{array}$ \\
\hline & & @ geloraco & $\begin{array}{l}\text { "Gelora News - Menggelorakan Persatuan | } \\
\text { Partner Forum Rekat Indonesia | Menyajikan } \\
\text { Berita yang Independen, Kritis dan Objektif } \\
\text { d" }\end{array}$ \\
\hline & & @ detikcom & "Official Twitter of http://detik.com" \\
\hline & & @ aniesbaswedan & $\begin{array}{l}\text { "Akun resmi Anies Baswedan, dikelola oleh } \\
\text { tim, kicauan pribadi ditandai - ABW. . } \\
\text { Governor of @ DKIJakarta." }\end{array}$ \\
\hline & & @ divhumas_polri & $\begin{array}{l}\text { "Akun Resmi Divisi Humas Polri. } \\
\text { IG:divisihumaspolri - FB:Divisi Humas Polri } \\
\text { - YT:Divisi Humas Polri | Obyektif, } \\
\text { Dipercaya, Partisipasi." }\end{array}$ \\
\hline & \multirow[t]{3}{*}{ Kluster G2 } & @ lettachantik & "NKRI. No DM" \\
\hline & & @ ferdinandhaean3 & $\begin{array}{l}\text { "Berpolitik Untuk Bangsa | NKRI ID } \\
\text { PANCASILA | Tak Mengejar Surga | Masih } \\
\text { Berbuat Dosa | Tak Beragama Tapi Br Tuhan } \\
\text { |" }\end{array}$ \\
\hline & & @ dinihrdianti & $\begin{array}{l}\text { "A wife+mother @ filosografi22. } \\
\text { \#RelawanNKRI \#GanjarNusantara } \\
\text { \#GANTARI. } 2012 \text { JKW for DKI㝋2014 }\end{array}$ \\
\hline
\end{tabular}




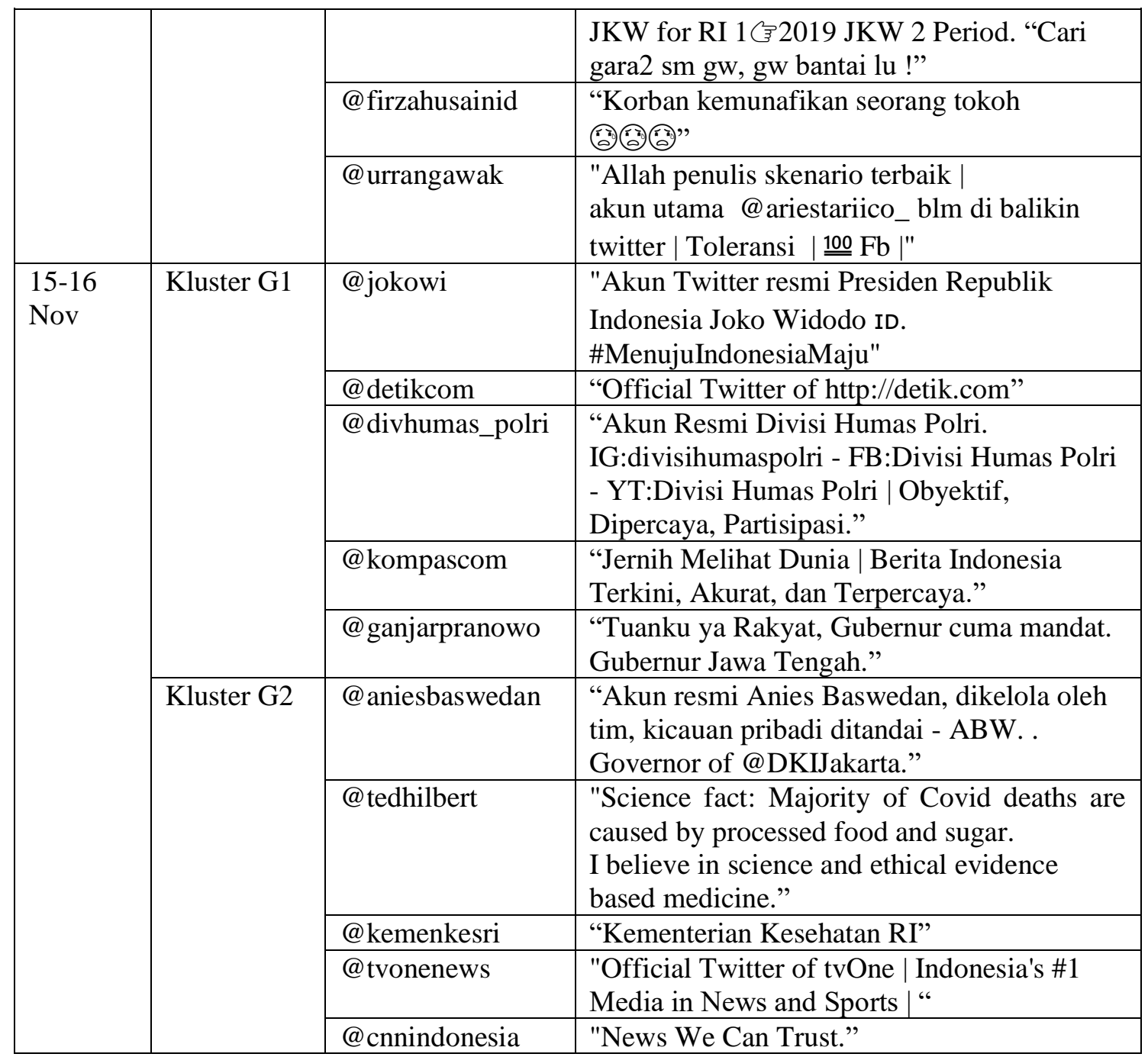

Tabel 04 Hasil identifikasi Lima hub teratas

Hasil temuan menunjukkan bahwa akun-akun resmi pemerintah/institusi (@ divhumas_polri), tokoh politik (@jokowi), serta media massa (@ detikcom) secara bersamaan muncul pada seluruh kumpulan data (13-16 November), sehingga mereka membentuk kluster yang secara konsisten mendukung keberhasilan program vaksinasi nasional. Selanjutnya pada kumpulan data periode 15-16 November terdapat akun pseudoscience (@ tedhilbert) yang muncul dan bergabung ke dalam kluster G2 yang mana sebelumnya (13-14 November) berada pada kluster G1. Pada kumpulan data 13-14 November terdapat kluster G2 dimana hub-nya mendukung keberhasilan program vaksinasi. Namun perbedaannya dengan akun hub pada kluster G1, akun hub pada kluster G2 terindikasi sebagai akun pendengung (buzzer) dan memiliki aktivitas bermedia sosial yang mirip seperti bot. Sehingga kluster G2 ini dapat diidentifikasi sebagai kluster "marketing". Namun, kluster ini tidak memiliki konsistensi karena pada kumpulan data 15-16 November kluster "marketing" ini tidak terbentuk, namun beberapa akun yang sempat menjadi hub berpindah ke kluster lain.

Menurut Felt (2016) terdapat beberapa alasan mengapa Twitter lebih menarik bagi ilmuan sosial dan analis data. Pertama, penelitian dengan menggunakan data Twitter dapat dilakukan dalam skala besar. Twitter dapat menampung setengah miliar kicauan per hari yang berasal dari 316 juta penggunanya. Kedua, Twitter dapat menghasilkan beragam jenis informasi yang dibutuhkan oleh peneliti. Ketiga, keterkaitan peneliti terhadap Twitter karena berhubungan dengan keinginan untuk memahami diskursus global yang terjadi. Jadi peneliti fokus terhadap 
Twitter karena ia dapat menjawab pertanyaan yang berkaitan dengan jaringan sosial, diskursus global, dan sentimen publik.

Pertama, penelitian yang dilakukan oleh Knolbach-Westermick dkk (2013) bertujuan untuk melihat pengaruh terpaan selektif terhadap pesan kesehatan. Metode yang digunakan adalah studi eksperimen terhadap 419 mahasiswa yang merupakan pengguna internet berat. Hasil yang didapatkan dalam penelitian ini menunjukkan bahwa terpaan selektif pada pesan kesehatan dipengaruhi oleh beberapa hal, yaitu adanya perilaku sebelumnya (self-bolstering) dan diskrepansi perilaku standar, di mana self-motivating lebih dominan daripada self-defending. Selain itu, hasil lain menunjukkan bahwa terpaan selektif lebih berdampak secara signifikan terhadap sumber terpercaya jika dibandingkan dengan sumber yang memiliki kredibilitas rendah.

Persamaan dengan kajian yang diteliti oleh peneliti adalah sama-sama meneliti terpaan selektif terhadap pesan/informasi kesehatan yang tersedia di internet. Akan tetapi penelitian di atas berfokus untuk mengidentifikasi faktor-faktor munculnya terpaan selektif terhadap pesan kesehatan. Sedangkan peneliti, berfokus untuk mengidentifikasi serta menganalisis kluster yang terbentuk dalam suatu populasi jaringan sosial. Secara singkat, peneliti menjadikan kluster sebagai unit analisis dalam penelitian ini. Hal ini kemudian yang membedakan dengan penelitian di atas yang menggunakan individu sebagai level analisisnya.

Selain itu dari segi pengumpulan data terdapat perbedaan dengan penelitian di atas. Penelitian ini akan mengumpulkan data publik yang berasal dari Twitter. Secara singkat perbedaan penelitian di atas dengan penelitian yang akan dilakukan terletak pada metode serta pendekatan yang akan digunakan.

Kedua, penelitian yang dilakukan oleh Prastyo dkk (2019) bertujuan untuk menganalisis faktor-faktor pembentuk disonansi kognitif pada wanita tunasusila serta cara mereka dalam mengatasinya. Metode yang digunakan adalah fenomenologi transendental di mana data didapatkan dari wawancara mendalam, dokumentasi, dan observasi. Narasumber dalam penelitian ini adalah para Pekerja Seks Komersial yang berada di Makam Kembang Kuning Surabaya. Hasil penelitian ini menunjukkan bahwa terjadi disonansi kognitif, di mana faktor penyebabnya adalah keluarga serta cemoohan atau pengucilan di masyarakat. Sehingga, untuk menghindari atau mengurangi disonansi ini maka akan terjadi perubahan perilaku (menjadi lebih terbuka atau tertutup) dan mencari informasi yang dapat mendukung perilakunya.

Persamaan dengan kajian yang diteliti oleh peneliti adalah sama-sama meneliti tentang terpaan selektif. Namun, penelitian di atas berfokus pada disonansi kognitif yang secara klasik dianggap sebagai munculnya terpaan selektif. Hal ini berbeda dengan penelitian yang akan dilakukan karena peneliti akan melakukan analisis jaringan sosial untuk memaknai data yang telah dianalisis.

Ketiga, penelitian yang dilakukan oleh Anggarini (2020) yang bertujuan untuk mendeskripsikan cara individu memproses informasi dan memaknai fenomena, pemberitaan, dan upaya pemerintah dalam menangani COVID-19. Metode yang digunakan adalah fenomenologi dengan melakukan wawancara mendalam terhadap empat informan yang selalu mengikuti berita COVID-19 di Kota Semarang. Hasil menunjukkan bahwa internet masih menjadi pilihan utama dalam mengakses informasi yang disebabkan oleh akses yang fleksibel. Selain itu, virus COVID19 dimaknai secara beragam serta pemberitaan virus COVID-19 dianggap berlebihan, terutama pada media elektronik, seperti televisi. Terakhir, pemerintah secara umum dianggap gagal dalam mengatasi penyebaran virus COVID-19.

Persamaan dengan kajian yang diteliti oleh peneliti adalah secara umum meneliti terkait sumber informasi serta cara individu memaknai virus COVID-19. Namun, berbeda dengan penelitian di atas, penelitian yang akan dilakukan lebih spesifik untuk membahas jaringan sosial yang terbentuk terkait vaksin COVID-19.

Keempat, penelitian yang dilakukan oleh Himelboim dkk (2020) yang bertujuan untuk mengetahui karakteristik konten dan pola diskusi terkait perdebatan vaksin HPV di Twitter. Penelitian ini menggunakan data log Twitter sebanyak 39.368 pengguna yang dikumpulkan dari 
tanggal 20 September 2016 hingga 10 minggu ke depan. Penelitian ini mengaplikasikan analisis jaringan sosial untuk mengidentifikasi kluster yang terbentuk karena adanya aktivitas posting dan sharing konten terkait vaksin HPV di Twitter. Selain itu, studi ini juga menggunakan analisis konten dengan mengaplikasikan bantuan komputer (computer-aided) dan koding secara manual. Terdapat beberapa hasil dari studi ini, yaitu (a) emosi positif berkorelasi positif terhadap densitas kluster, di mana hal tersebut dapat mempengaruhi ikatan yang kuat dan turut mempengaruhi kecepatan arus informasi; (b) emosi marah merupakan prediktor emosi negatif yang signifikan terhadap densitas grafik; dan (c) terdapat korelasi antara certainty dan tentativeness pada level kluster.

Persamaan dengan kajian yang diteliti oleh peneliti adalah sama-sama menggunakan analisis jaringan sosial dalam mengidentifikasi kluster, atau menggunakan metode kluster terpaan selektif. Selain itu, kesamaan lainnya adalah menggunakan data Twitter sebagai subjek penelitian. Adapun perbedaan dengan penelitian di atas adalah pada populasi penelitian yang digunakan. Penelitian yang akan dilakukan akan menggunakan populasi pengguna Twitter di Indonesia. Selain itu, topik yang akan diteliti peneliti terkait dengan vaksin COVID-19. Terakhir, perbedaan terletak pada analisis yang digunakan, penelitian yang akan dilakukan hanya akan menggunakan metode kluster terpaan selektif.

\section{KESIMPULAN}

Pembentukan kluster informasi pada hubungan sosial pada media sosial twiter memberikan pengaruh positif terhadap kebijakan pemerintah dalam program vaksinasi nasional di Indonesia. Hal itu dibuktikan bahwa akun-akun resmi pemerintah/institusi (@divhumas_polri), tokoh politik (@jokowi), serta media massa (@detikcom) secara bersamaan muncul pada seluruh kumpulan data (13-16 November), sehingga mereka membentuk kluster yang secara konsisten mendukung keberhasilan program vaksinasi nasional. Pembentukan kluster infromasi pada media sosial mengurangi sentimen negatif terhadap program vaksinasi nasional, dimana banyaknya informasi yang biasa diperoleh masyarakat sehingga tidak mau divaksin dengan alasan adanya efek samping yang bisa mempengaruhi kesehatan mereka. Selanjutnya pada kumpulan data periode 15-16 November terdapat akun pseudoscience (@ tedhilbert) yang muncul dan bergabung ke dalam kluster G2 yang mana sebelumnya (13-14 November) berada pada kluster G1. Pada kumpulan data 13-14 November terdapat kluster G2 dimana hub-nya mendukung keberhasilan program vaksinasi. Namun perbedaannya dengan akun hub pada kluster G1, akun hub pada kluster G2 terindikasi sebagai akun pendengung (buzzer) dan memiliki aktivitas bermedia sosial yang mirip seperti bot. Sehingga kluster G2 ini dapat diidentifikasi sebagai kluster "marketing". Namun, kluster ini tidak memiliki konsistensi karena pada kumpulan data 15-16 November kluster "marketing" ini tidak terbentuk, namun beberapa akun yang sempat menjadi hub berpindah ke kluster lain.

\section{DAFTAR PUSTAKA \\ Buku}

Cangara, H. (2014). Pengantar Ilmu Komunikasi. PT. Raja Grafindo Persada.

Festinger, L. (1957). A theory of social cognitive dissonance. Standford University Press.

Festinger, L. (1968). Theory Cognitive Dissonance. Standford University Press.

Hansen, D. L., Shneiderman, B., \& Smith, M. A. (2011). Analyzing Social Media Networks with NodeXL: insights From a Connected World. Morgan Kaufmann. http://site.ebrary.com/lib/alltitles/docDetail.action?docID=10408229\%5Cnhttp://www.ama zon.com/gp/product/0123822297? ie =utf $8 \&$ tag $=$ conneactio-

$20 \&$ linkcode $=$ as $2 \&$ camp $=1789 \&$ creative $=390957 \&$ creativeasin $=0123822297$

Holmes, D. E. (2017). Big Data: A Very Short Introduction. Oxford University Press.

Prior, M. (2007). Post-Broadcast Democracy. Cambridge University Press. https://doi.org/10.1017/CBO9781139878425 
Sloan, L., Quan-Haase, A., Mayr, P., \& Weller, K. (2017). The SAGE Handbook of Social Media Research Methods. In M. Steele (Ed.), The SAGE Handbook of Social Media Research Methods. Sage Publication Ltd. https://doi.org/10.4135/9781473983847.n8

Sugiyono. (2013). Metode Penelitian Kuantitatif Kualitatif dan R\&D. Alfabeta.

Stroud, N. J. (2014). Selective Exposure Theories. The Oxford Handbook of Political Communication, l(July), 1-21. https://doi.org/10.1093/oxfordhb/9780199793471.013.009

\section{Daring}

Afifah, M. N. (2021). Kenali Arti Efikasi Vaksin, Berbeda dari Efektivitas. Kompas.Com.

Kawalcovid19.id. (2021). Kawal informasi seputar COVID-19 secara tepat dan akurat.

Namira, I. (2020). 7 Fakta "Ngeri" Filter Bubble, Gelembung Virtual Penyaring Informasi. Idntimes.Com. https://www.idntimes.com/tech/trend/izza-namira-1/fakta-filter-bubble/1

Neuron. (2021). Apa Bedanya 5 Vaksin Korona Ini? Youtube.

Pusparisa, Y. (2021). Daftar Negara Pengguna Smartphone Terbanyak, Indonesia Urutan Berapa? Databoks.Katadata.Co.Id. https://databoks.katadata.co.id/datapublish/2021/07/01/daftar-negara-penggunasmartphone-terbanyak-indonesia-urutan-berapa

Putri, V. K. M. (2021). Hyperlink: Pengertian, Jenis, Fungsi dan Cara Membuatnya. Kompas.Com.

Sekretariat Kabinet Republik Indonesia. (2021). Presiden Jokowi Terima Suntukan Dosis Pertama Vaksin COVID-19. https://setkab.go.id/presiden-jokowi-terima-suntikan-dosispertama-vaksin-covid-19/

Twitter. (2021). Twitter API.

\section{Ensiklopedia}

Gruzd, A. (2014). Encyclopedia of Social Network Analysis and Mining. In Encyclopedia of

\section{Jurnal} Social Network Analysis and Mining. https://doi.org/10.1007/978-1-4614-6170-8

Acter, T., Uddin, N., Das, J., \& Akhter, A. (2020). Evolution of severe acute respiratory syndrome coronavirus 2 (SARS-CoV-2) as coronavirus disease 2019 (COVID-19) pandemic: A global health emergency. Science of the Total Environment Journal, N/V(January), 2-15. https://doi.org/https://dx.doi.org/10.1016\%2Fj.scitotenv.2020.138996

Adriana, Z. (2015). Communication Pattern Instructor Use of Cyber Extension at Secretariat Agency Coordination Counseling Province Riau. JOM, 2(1).

Anggarini, S. (2020). Fenomena Dalam Berita Covid-19. Jurnal Audience, 3(2), 224-249. https://doi.org/10.33633/ja.v3i2.3628

Arora, P. (2012). Typology of Web 2.0 spheres: Understanding the cultural dimensions of social media spaces. Current Sociology, 60(5), 599-618. https://doi.org/10.1177/0011392112440439

Aruguete, N., \& Calvo, E. (2018). Time to \#protest: Selective exposure, cascading activation, and framing in social media. Journal of Communication, 68(3), 480-502. https://doi.org/10.1093/joc/jqy007

Barberá, P., Jost, J. T., Nagler, J., Tucker, J. A., \& Bonneau, R. (2015). Tweeting From Left to Right. Psychological Science, 26(10), 1531-1542. https://doi.org/10.1177/0956797615594620

Emarita, N., Suryana, A., \& Aristi, N. (2012). Hubungan antara Pencarian Informasi Melalui Twitter@BdgBerkebun dengan Pemenuhan Kebutuhan Informasi. Jurnal Manajemen Komunikasi Fakultas Ilmu Komunikasi Universitas Padjajaran, 1(1), 1-14.

Felt, M. (2016). Social media and the social sciences: How researchers employ Big Data analytics. Big Data and Society, 3(1), 1-15. https://doi.org/10.1177/2053951716645828

Freedman, J. L., \& Sears, D. O. (1965). Selective Exposure. Advances in Experimental Social Psychology, 2(C), 57-97. https://doi.org/10.1016/S0065-2601(08)60103-3 
Gruzd, A., \& Mai, P. (2020). Going viral: How a single tweet spawned a COVID-19 conspiracy theory on Twitter. Big Data and Society, 7(2). https://doi.org/10.1177/2053951720938405

Hardianto, G., Erlamsyah, E., \& Nurfahanah, N. (2016). Hubungan antara Self-Efficacy Akademik dengan Hasil Belajar Siswa. Konselor, 3(1), 22. https://doi.org/10.24036/02014312978-0-00

Himelboim, I., Smith, M., \& Shneiderman, B. (2013). Tweeting Apart: Applying Network Analysis to Detect Selective Exposure Clusters in Twitter. Communication Methods and Measures, 7(3), 169-197. https://doi.org/10.1080/19312458.2013.813922

Himelboim, I., Xiao, X., Lee, D. K. L., Wang, M. Y., \& Borah, P. (2020). A Social Networks Approach to Understanding Vaccine Conversations on Twitter: Network Clusters, Sentiment, and Certainty in HPV Social Networks. Health Communication, 35(5), 607-615. https://doi.org/10.1080/10410236.2019.1573446

Islam, A. K. M. N., Laato, S., Talukder, S., \& Sutinen, E. (2020). Misinformation sharing and social media fatigue during COVID-19: An affordance and cognitive load perspective. Technological Forecasting and Social Change, 159, 120201. https://doi.org/10.1016/j.techfore.2020.120201

Jonas, E., Schulz-Hardt, S., Frey, D., \& Thelen, N. (2001). Confirmation bias in sequential information search after preliminary decisions: An expansion of dissonance theoretical research on selective exposure to information. Journal of Personality and Social Psychology, 80(4), 557-571. https://doi.org/10.1037/0022-3514.80.4.557

Khaerunnisa Syafitri, N., Rullyana, G., \& Ardiansah, A. (2020). autobase@collegemenfess, A Twitter Account Used as Information Retrieval Tool. Khizanah Al-Hikmah: Jurnal Ilmu Perpustakaan, Informasi Dan Kearsipan, 8(2), 161-172. https://doi.org/10.24252/kah.v8i2a6

Kitchin, R. (2014). Big Data, new epistemologies and paradigm shifts. Big Data and Society, 1(1), 1-12. https://doi.org/10.1177/2053951714528481

Kitchin, R., \& McArdle, G. (2016). What makes Big Data, Big Data? Exploring the ontological characteristics of 26 datasets. Big Data and Society, 3(1), 1-10. https://doi.org/10.1177/2053951716631130

Knobloch-Westerwick, S., Johnson, B. K., \& Westerwick, A. (2013). To your health: SelfRegulation of health behavior through selective exposure to online health messages. Journal of Communication, 63(5), 807-829. https://doi.org/10.1111/jcom.12055

Kurniawan, R., \& Apriliani, A. (2020). ANALISIS SENTIMEN MASYARAKAT TERHADAP VIRUS CORONA BERDASARKAN OPINI DARI TWITTER BERBASIS WEB SCRAPER. Jurnal INSTEK (Informatika Sains Dan Teknologi), 5(1), 67. https://doi.org/10.24252/instek.v5i1.13686

Lewis, S. C., Zamith, R., \& Hermida, A. (2013). Content Analysis in an Era of Big Data: A Hybrid Approach to Computational and Manual Methods. Journal of Broadcasting and Electronic Media, 57(1), 34-52. https://doi.org/10.1080/08838151.2012.761702

McGuire, W. J., \& Papageorgis, D. (1961). The relative efficacy of various types of prior beliefdefense in producing immunity against persuasion. The Journal of Abnormal and Social Psychology, 62(2), 327-337. https://doi.org/10.1037/h0042026

Nasution, B., Rumyeni, R., \& Rimayanti, N. (2019). Perilaku Pencarian Informasi Pemilihan Umum Tahun 2019 Pemilih Pemula di Kota Pekanbaru. Jurnal Komunikatif, 8(2), 191-204. https://doi.org/10.33508/jk.v8i2.2212

Pambudi, H. J., Nugroho, A. L. A., Handoko, L., \& Dianastiti, F. E. (2021). BUZZER DI MASA PANDEMI COVID-19: STUDI ANALISIS WACANA KRITIS KICAUAN BUZZER DI TWITTER. Jurnal Masyarakat Dan Budaya, 23(1), 75-89. https://doi.org/https://doi.org/10.14203/jmb.v23i1.1265

Papacharissi, Z., \& De Fatima Oliveira, M. (2012). Affective News and Networked Publics: The Rhythms of News Storytelling on \#Egypt. Journal of Communication, 62(2), 266-282. 
https://doi.org/10.1111/j.1460-2466.2012.01630.x

Parks, M. R. (2014). Big Data in Communication Research: Its Contents and Discontents. Journal of Communication, 64(2), 355-360. https://doi.org/10.1111/jcom.12090

Prastyo, I., Suryanto, \& Rini, A. P. (2019). Disonansi Kognitif Wanita Pekerja Seks Komersial yang Bekerja Menghidupi Keluarga. PSISULA, 1(September), 74-83. https://doi.org/http://dx.doi.org/10.30659/psisula.v1i0.7693

Riani, N. (2017). MODEL PERILAKU PENCARIAN INFORMASI GUNA MEMENUHI KEBUTUHAN INFORMASI (STUDI LITERATUR). Publication Library and Information Science, 1(2), 14. https://doi.org/10.24269/pls.v1i2.693

Rohmiyati, Y. (2018). Model Perilaku Pencarian Informasi Generasi Milenial. Anuva, 2(4), 387. https://doi.org/10.14710/anuva.2.4.387-392

Saud, M., Mashud, M., \& Ida, R. (2020). Usage of social media during the pandemic: Seeking support and awareness about COVID-19 through social media platforms. Journal of Public Affairs, 20(4), e02417. https://doi.org/10.1002/pa.2417

Syafganti, I. (2018). Digital Transformation, Big Data and Research Landscape in Digital Communication. Jurnal Komunikasi Ikatan Sarjana Komunikasi Indonesia, 3(2). https://doi.org/10.25008/jkiski.v3i2.220

Syarifuddin, M. (2020). ANALISIS SENTIMEN OPINI PUBLIK MENGENAI COVID-19 PADA TWITTERMENGGUNAKAN METODE NAÏVE BAYESDAN KNN. Inti Nusa Mandiri, 15(1), 23-28. https://doi.org/https://doi.org/10.33480/inti.v15i1.1347

Wei, L., \& Hindman, D. B. (2011). Does the digital divide matter more? Comparing the effects of new media and old media use on the education-based knowledge gap. Mass Communication and Society, 14(2), 216-235. https://doi.org/10.1080/15205431003642707

Wirawanda, Y., \& Wibowo, T. O. (2018). TWITTER: Expressing Hate Speech Behind Tweeting. Profetik: Jurnal Komunikasi, 11(1), 5. https://doi.org/10.14421/pjk.v11i1.1378

\section{Laporan}

Kemp, S. (2021). DIGITAL 2021: INDONESIA.

Wearesocial.com. (2021). Digital 2021.

\section{Prosiding}

Duan, W., Cao, Q., Yu, Y., \& Levy, S. (2013). Mining online user-generated content: Using sentiment analysis technique to study hotel service quality. Proceedings of the Annual Hawaii International Conference on System Sciences, 3119-3128. https://doi.org/10.1109/HICSS.2013.400

Liao, Q. V., Fu, W. T., \& Mamidi, S. S. (2015). Is all about perspective: An exploration of mitigating selective exposure with aspect indicators. Conference on Human Factors in Computing Systems - Proceedings, 2015-April, 1439-1448. https://doi.org/10.1145/2702123.2702570

Tsou, M. H. (2011). Mapping Cyberspace: Tracking The Spread Of Ideas On The Internet. 25th International Cartographic Conference, 43. https://icaci.org/files/documents/ICC_proceedings/ICC2011/Oral Presentations PDF/D3Internet, web services and web mapping/CO-354.pdf 